\title{
PILGRIMAGE TOURISM IN OUR COUNTRY (SAMARKAND EXAMPLE)
}

\author{
Bahronov Sherzod Abdugafforovich \\ Assistant, Samarkand Institute of Economics and Service
}

Nurmatova Saadiniso Akbar qizi

Student, Samarkand Institute of Economics and Service

Uralov Shokhrukhbek Askaraliyevich

Student, Samarkand Institute of Economics and Service

Article DOI: https://doi.org/10.36713/epra5784

\section{ANNOTATION}

In the article you will get detailed concepts about visiting tourism and information about the tombs and squares, mosques of the magnificent landmarks that can be visited.

KEYWORDS: tourist, tourism, mausoleum, mosque, pilgrimage, field.

\section{DISCUSSION}

Our motherland is considered as a congestion of sacred pilgrimage places. As is currently happening in other areas, visitors and tourists are provided with a wide range of conditions and opportunities. The discounts on public holidays, discounts on plane and train tickets for family visits and travelers, bring joy to the hearts of every citizen living in our country. What do we understand when one says to pigrimage in general?

"Pilgrimage" means "go and see" in the dictionary. Pilgrimage is- going to holy places, cemeteries and shrines and perform certain rituals. But this is not just a journey, it means an opportunity to realize oneself, a path leading to faith, hoping for spiritual purification, seeking blessings and positive desires. This is- appeal to the Almighty through the past Saints, to calm his mind and soul, to understand the truth of inevitability, to go through the path of loneliness and purification.

Uzbekistan has been a center of intersection of many cultures and civilizations since long historical times. Various religions have been propagated here, so unique monuments belonging to the religions of Islam, Buddhism and Christianity have been preserved.

There are many places of pilgrimage in our country. Our people have learned the courage and names of the great scientists, Saints and great commanders who lived in ancient times. If there is a possibility, five or ten people will come together and go on a trip to the ancient settlements of Bukhara, Khorezm, Fergana or Samarkand. They visit the monuments left from our ancient ancestors, the mausoleums of saints such as Imam Bukhari, Margilani, Termiziy, Zamakhshari, Pahlavon Mahmud and give Qur'an to their souls. Those who have kinked Nazr-u Niyaz, Sadakai-Ekhsan to their heart, would not hesitate visiting ancient cities of the Turkestan or go to the sides of the blindfold, of course. On the territory of Uzbekistan, like other religions, there are many sacred places related to Islamic culture and its Sufi flow. And the most valuable monuments are recognized as UNESCO's all-round heritage sites. Among them is the city of Bukhara, which is called Bukhari-Sharif, that in the Islamic world means blessed Bukhara. The city of Samarkand, the homeland of Amir Temur has many 
invaluable monuments, and is Shakhrisabz city. Of course, these cities have an ancient and rich history and have undergone serious changes in the history.

The idea of Eternity has a connection with these cities. In the biography of the Prophet Muhammad, there is a story. He had a heavenly horse, and he rises to heaven on that horse. First he visits Jerusalem, then Mecca. Looking at Mecca, he sees that the sun's rays illuminate the whole world. Then he sees only two rays on Earth, these rays rose up from the ground. These rays were Bukhara and Samarkand.

Two hundred years after the birth of Jesus Christ, the first Christians appeared in Movarounnahr. Their churches and temples have been inhabited for centuries with the temples of zoroastrians, and later with the mosques of Muslims. Many famous monuments, known as mosques now, were churches formerly, for example, the Poi-Kalon mosque in Bukhara.

The appearance of Christianity in Central Asia at the beginning of the first millennium BC depends on the Apostle Foma, who served as a missionary in this region, connected with the name of the first-called Andrei. Since then, the two most common religions in the world - Islam and Christianity have been living peacefully together. There are more than 10 holy and revered Christian places and places of pilgrimage in Uzbekistan at all. For example, the Cathedral of the Holy Heart of Jesus Christ in Tashkent City.

Up till now, on the territory of Uzbekistan, the chashmai Ayyub shrine, which both Christians and Muslims respect, is located in Bukhara. Directly, the Orthodox Church in Uzbekistan began to form with the emergence of the Russian Orthodox Church in Central Asia, after the main part of this region was annexed to the Russian Empire and along with the establishment of the Turkistan general-governor's office (1867).

Another ancient religion that influenced the cultural diversity of Central Asia and Afghanistan is Buddhism. In 1968, a Buddha statue was found in the territory of the ancient Termez, and that place became the main object studied by many archeologists. Later, the complexes of the oldest Buddhist temples were opened: Fayoztepa ( 1-th century BC - 3-th century AD), Kamirtepa, Karatepa. The discovery of the elements of the Ayritom Frieze, famous for the image of ancient musicians, indicates that Buddhism was propagated in the territory of this region and that elements of ellinistic culture were revealed. Now the Terracotta bas-reliefs of the embroidered border are stored in the State Hermitage Museum in St. Petersburg.

Speaking about tourism, the most tourist cities in our country are Samarkand, Bukhara, Khiva and Tashkent. As an example, let's talk about the places of visits of the Samarkand city.

It is desirable for those who visited Samarkand for the first time, initially, to get acquainted with the monuments of ancient patterned architecture of the city. You will feel how much this city in the Middle Ages, which has huge minarets and immortal monuments with blue domes, has found its legend from the skill of the incarnation of an unprecedented power that has been preserved up till today.

\section{Registan Square}

This area is one of the most important and noteworthy in the city, and as an ancient but always urban ensemble, the fame has gone to the whole world. It is surrounded by three powerful madrasah buildings, each individually decorated with a unique pattern. As an excellent example of Oriental architecture, Samarkand is included in the UNESCO list of All-World Heritage sites.

\section{Amir Temur mausoleum}

The historical monument of Gori-Amir was built at the beginning of the 15 th century and is a great creative example of Uzbek architectural art. The madrasah was built as a place of science, providing education to the children of famous intellectuals in the city. The construction of the building was started by Muhammad Sultan and he intended to open an Islamic Education Center.

\section{Tomb of Islam Karimov}

The restoration of the memorial complex was carried out in cooperation with Unesco and approved the project of a shrine adapted to the Hazrati Khizr mosque, which is considered one of the objects of the world cultural heritage.

On the territory of complex, was built a veranda of national style. All conditions have been created here for visitors, seats have been installed. Verses of the Qur'an and wise words of Islam Karimov are written in Uzbek, Arabic and English on the archs. Every year on January 30, flowers are laid in the Islam Karimov mausoleum complex by activists from the Republic of Karakalpakstan, all regions and the city of Tashkent, the general public, representatives of various offices and organizations, residents of the Samarkand region. The memory of the first president is memorized and the Qur'an is recited.

\section{Mosque of Bibikhanim}

Amir Temur, in terms of size and beauty, built a beautiful mausoleum that surpasses other monuments on the planet and presented it to his woman. Gilded walls, high-built elements of the structure, elaborately carved marble stones, the building dome are supposed to serve to seal in history names of Amir Temur and his wife.

\section{Afrasiab town}


Afrasiab is a large archaeological monument and reflects the history of the ancient city of Samarkand. The area of the ancient city is 219 hectares. Archaeologists have found that there are 11 cultural layers that cross each other. In the modern release of the city, the ruins of the mighty fortress, the walls of the dilapidated defense, it is possible to easily distinguish the rubble of the canal from which water comes to the city at any time.

\section{Mosque of Shakhi Zinda}

The Tomb of Shakhi Zinda is one of the ancient osari-relics, which contains colorful grave stones in the city of Samarkand, is amazing. The peculiarity of this historical monument is that it closely harmonizes all the structures built during the XIV-XV centuries. These buildings were erected near the ancient city of Afrasiab, and the street on which the building was located was also called "Mausoleum Street".

\section{Ulugbek Observatory}

Ulugbek-the original name Muhammad Taragay is great Uzbek astronomer and mathematician, statesman, grandson of Amir Temur. He is one of the scientists who brought the science and culture of the peoples of Central Asia to the forefront of World Science in the conditions of the Middle Ages. In movarounnahr during the period of Ulugbek's patronage (1409-1449) Samarkand flourished even more: art, architecture, literature became popular, science rose, trade developed. Ulugbek has a great scientific and cultural heritage, which has made an important contribution to the development of World Science and culture. One of them is the Ulugbek Observatory. It is one of the rare examples of the 15 th century architecture in Samarkand. The building was built by the decree of Ulugbek in 1424-1429 on The Hill of Kohak (Shepherd father), on the banks of the river Abirahmat.

\section{Place of pilgrimage Hazrati Davud}

In the next times, the Hazrati Davud cave, located in Nurabad District of Samarkand region, Oksoy village, has become one of the busiest places of pilgrimage in Uzbekistan. This cave has hidden very ancient and diverse legends, and the number of visitors to it is growing day by day.

\section{Place of pilgrimage Hazrati Daniyar}

The mausoleum of Daniyar Prophet, which has been appreciated by the people of Samarkand for centuries on the banks of the Siyab aryk, which flows under the protection wall of the ancient city of Afrasiab in Samarkand, is one of the most magnificent places of pilgrimage.

\section{Imam Al-Bukhari mausoleum}

The name of Imam Al-Bukhari is famous all over the Eastern world, and he is one of the greatest devouts. In his collection of Hadiths, he left more than 600 000 manuscripts about the events told by our Prophet Alaihivassalam and rich in wisdom related to him in their lives.

\section{The Siyab bazaar}

The Siyab bazaar is the oldest and largest bazaar not only in the city of Samarkand, but also in Uzbekistan and Central Asia. The area of mart is 7 hectares. The Siyab bazaar is one of the most visited places by tourists. Its name is attributed to the name of one of the historical-geographical districts of the city Siyab, as well as the Siyab River, which flows close to the mart. "Siyab" in translation from Persian-Tajik means "ink ob" - "black water/river".

The above-mentioned mausoleum, mosques, squares are both pilgrimage and tourist places of Samarkand City. In conclusion, we can say that the number of tourists in the city of Samarkand is growing on a large scale. The city of Samarkand has a rich history, and every tourist who comes to this land returns with an unusual influence.

\section{REFERENCES}

1. http://uzbekistan-geneva.ch/ziyorat-turizmijadal-rivojlanadi.html

2. http://sammuslim.uz/oz/articles/ziyorat-odoblari

3. https://uzbekistan.travel/uz/v/ziyorat-turizmi/

4. https://abasayyoh.com/ru/pages/176

5. https://zamin.uz/uz/hayot-tarzi/19439-negaziyorat-qilamiz.html 